\title{
MOVING PEOPLE TO DELIVER SERVICES: HOW CAN THE WTO HELP?
}

\author{
Sumanta Chaudhuri* \\ Aaditya Mattoo** \\ Richard Self***
}

\begin{abstract}
The previous General Agreement on Trade in Services (GATS) negotiations produced little liberalization of the movement of individual service providers (mode 4), and the potentially large global gains from such movement remain unrealized. In the current negotiations, as part of the Doha Development Agenda, developing countries are seeking greater openness in their area of comparative advantage: the movement of providers unrelated to commercial presence abroad. At the same time, many multinational firms would like easier intra-corporate movement of their personnel. We describe how this coincidence of interest could be harnessed to deliver greater openness at least for skilled service providers.
\end{abstract}

World Bank Policy Research Working Paper 3238, March 2004

The Policy Research Working Paper Series disseminates the findings of work in progress to encourage the exchange of ideas about development issues. An objective of the series is to get the findings out quickly, even if the presentations are less than fully polished. The papers carry the names of the authors and should be cited accordingly. The findings, interpretations, and conclusions expressed in this paper are entirely those of the authors. They do not necessarily represent the view of the World Bank, its Executive Directors, or the countries they represent. Policy Research Working Papers are available online at http:/lecon.worldbank.org.

*Permanent Mission of India to the WTO, **World Bank, ***Nathan Associates. The comments of Crawford Falconer, Alejandor Jara, Hamid Mamdouh, Deepak Mishra, Julia Nielson, Anya Oram, Anirudh Shingal, B.K. Zutshi, participants in seminars in India, Geneva and Paris, and an anonymous referee are gratefully acknowledged. 


\section{MOVING PEOPLE TO DELIVER SERVICES: HOW CAN THE WTO HELP?}

Negotiations on the "temporary presence of natural persons"(mode 4) first took place during the Uruguay Round of trade talks under the General Agreement on Trade in Services (GATS), but they were not particularly successful. In fact, they served primarily to facilitate exploratory business visits and the movement of high-level personnel within multinational corporations. Developing countries were disappointed by the dearth of commitments in their area of comparative advantage - that is, the movement of individuals unrelated to a commercial presence abroad (foreign direct investment or FDI) and are now seeking greater openness. At the same time, many multinational firms would like to see more scope for international movement of their personnel. This shared interest has created an unusual, though still guarded, sense of optimism about mode 4 negotiations in the current round of GATS negotiations.

This note describes how this coincidence of interest can be harnessed to deliver greater openness. Section I describes briefly the economic and political context for the discussion. Section II provides a critical assessment of the current rules and commitments under GATS. The proposed framework for negotiating liberalization commitments is presented in Section III.

\section{Mode 4: The Economic and Political Backdrop IN A NUMBER OF SERVICE SECTORS, MODE 4 WILL REMAIN A VITAL MODE OF DELIVERY}

There is little doubt that despite the dramatic development in technologies for electronic delivery, mode 4 will remain important for a range of services. Even in the software industry, for example, the movement of service-supplying personnel remains crucial: although the share of onshore services has declined, nearly half of Indian software exports are still supplied through the temporary movement of programmers to the client's site overseas. The dominance of onshore delivery stems from the need for continual clientdeveloper interaction, a reduction in information asymmetries regarding the performance of programmers, and demands by programmers to be sent abroad, in part to improve their skills and to gain access to international markets. ${ }^{1}$ In fact, as their populations age and their average levels of training and education rise, developed countries will face an increasing scarcity, in particular, of moderately and less skilled labor. Given that there is really no substitute for human labor, at least in some occupations (e.g., the caring occupations, personal services, and a range of professional services), the demand for mode 4 is likely to increase over time.

\section{BUT MODE 4 FACES A RANGE OF STRINGENT BARRIERS}

The barriers are fairly uniform across countries and fall into the following broad categories.

- Visa formalities are in themselves a significant obstacle, and the conditions attached are used to implement some of the restrictions listed below. One source of the problem is that the temporary movement of service providers invariably comes under the purview, not of international trade policy, but of immigration legislation and labor market policy.

\footnotetext{
${ }^{1}$ Often a strong complementary relationship exists between modes. For example, even to take advantage of open trading conditions under mode 1 usually requires some movement under mode 4 (Parikh, 2003).
} 
- Prohibitions and quotas on foreign providers are imposed either explicitly or through requirements of a prior adequate search for national service providers (e.g. in France in construction, research and development and higher education services). A somewhat weaker requirement is that employers take timely and significant steps to recruit and retain sufficient national workers and that no worker be laid off for a certain period preceding and following the filing of any work permit or visa application (e.g. in the United States for speciality occupations). In fact, the widespread use of economic needs tests has emerged as one of the major barriers to the free movement of service providers (OECD, 2002). The discretionary and non-transparent nature of such tests certainly reduces the predictability of trading conditions.

- Wage-parity conditions imply that wages paid to foreign workers should be similar to the existing wages paid to nationals in that profession (e.g. in the US). Although this requirement is intended to provide a non-discriminatory environment, it tends to erode the cost advantage of hiring foreigners and works like a de facto quota.

- Discriminatory treatment is implemented through a variety of internal instruments and is also a major impediment. Residency or citizenship requirements are frequently imposed as eligibility conditions, putting foreign providers at an immediate disadvantage. Then there is discrimination through social security contributions and taxes. For example, in the United States, foreign service providers have to pay Social Security and other taxes for which they do not get adequate tax credits in their home countries. ${ }^{2}$ Discrimination also often takes the form of preferences in government procurement granted to domestic service providers over foreigners.

- Non-recognition of professional qualifications and burdensome licensing requirements can be an impediment in regulating professions. The requirement of registration with, or membership of, professional organizations also constitutes an obstacle for a person wishing to provide the service on a temporary basis. Certain services, such as those of IT service providers, are not regulated, and many that are regulated allow for trade through subcontracting (e.g., a U.S. consumer may be obliged to use a U.S. architect, but the U.S. architect may buy the services of a foreign architect). In these areas, regulatory barriers are probably less serious impediments. But barriers exist in other regulated professions, ranging from doctors to lawyers. The difficulty here is in distinguishing between the legitimate denial of recognition and the denial that has a protectionist motive.

\section{THE ELIMINATION OF IMPEDIMENTS WOULD GENERATE SUBSTANTIAL GAINS FOR BOTH EXPORTING}

\section{AND IMPORTING COUNTRIES}

To date, mode 4 has defeated attempts to fit it into a robust analytical model (Winters et al., 2002). At one extreme, it can be viewed as no different from cross-border services trade (mode 1), which, in turn, is often pronounced to be no different analytically from ordinary goods trade. At the other extreme, mode 4 has much in common with regular migration, in which workers relocate from one country to another. This is particularly true when the periods of stay are long or where a particular job in country B is filled by a continual flow of temporary workers from country A, each being replaced by another as his or her contract expires. Thus another area relevant to an understanding of mode 4 is the economics of factor mobility.

The very basis of international trade, be it in goods or in factors, is the scope for exploiting differences. The larger the differences, the larger are the potential gains from opening up international trade. In the case of mode 4, potentially large returns would be feasible if medium and less skilled workers, who are relatively abundant in developing countries and for whom the proportionate gap in productivity between

\footnotetext{
${ }^{2}$ For example, Desai et al. (2000) estimate that the U.S. government collects as much as $\$ 22.5$ billion a year in the form of payroll taxes from $\mathrm{H} 1 \mathrm{~B}$ visa holders of Indian origin alone.
} 
home and host countries is greatest, were allowed to move and provide their services in developed countries. The existing empirical studies of factor mobility and the new estimates by Winters (2002) agree that there are huge returns to even relatively small movements of labor. For example, it is estimated that an increase in developed countries' quotas on the inward movements of both skilled and unskilled temporary workers equivalent to 3 percent of their work forces would generate an increase in world welfare of over US\$150 billion a year. Both developed and developing countries would share in these gains, and they would be largest if both high-skilled mobility and low-skilled mobility were permitted.

While these estimates are broadly plausible, neither of the polar models-trade or migration - captures the full essence of mode 4 mobility. From the host country point of view, temporary presence does avert some of the social and political costs of permanent migration but it entails other "turnover" costs, both for employing firms and society (e.g. in terms of recurring investment in firm-specific technical and limited social integration). From the home country point of view, temporary migration under mode 4 averts the costs of brain drain, implying a higher repatriation of incomes and skills, but it deprives migrants of opportunities for cumulative learning and saving - which could have significant long-term benefits for home countries, quite apart from immediate gains in terms of increased remittances. ${ }^{3}$ More conceptual and empirical analysis of these issues is clearly necessary.

\section{MODE 4 LIBERALIZATION PROVOKES LEGITIMATE POLITICAL AND SOCIAL CONCERNS-BUT MOST}

\section{OF THESE CAN BE ADDRESSED THROUGH APPROPRIATE POLICIES}

As Winters (2003) points out, unlike with the mass migration of less skilled workers, fears about cultural identity, problems of assimilation, and the drain on the public purse are not really relevant to mode 4. Host country concerns, other than the purely xenophobic, pertain to national security, the difficulty in enforcing temporariness, and the impact on the labor market.

In some cases, these difficulties would be alleviated, though not eliminated, if it could be ensured that movement will be temporary, not permanent. A key challenge is to devise a pre-commitment mechanism in this respect. The enforcement difficulties are evidently less with intra-corporate transferees - the local juridical presence can be penalized - than with independent service providers. Some have proposed the posting of a bond as a solution to this problem (Hatcher, 2003).

In other cases, the fears about permanent presence are outweighed by fears about job instability and wage and salary erosion. On social equity grounds, there is a particularly strong concern about the impact of mode 4 liberalization on local less skilled workers. ${ }^{4}$ The adjustment stresses that mode 4 liberalization could engender could be both large and concentrated on a vulnerable section of society (Winters, 2003). In the short run, sensitivity about the timing and extent of liberalization may contain the pressures and existing compensatory schemes could cope with those that actually arise. In the longer run, when deeper

\footnotetext{
${ }^{3}$ A recent survey for the Public Policy Institute of California of more than 1,500 first-generation Indian and Chinese migrants in Silicon Valley found that 74 percent of Indian and 53 per cent of the Chinese ones said they hoped to start a business back home. Furthermore, based on the finding that many members of this group frequently return home on business, it argues that "brain circulation" is a more appropriate way of describing what is happening to these groups than "brain drain" (Economist, November 2, 2002).

${ }^{4}$ Some worker representatives emphasize a slightly different set of issues relevant to ensuring that workers, domestic and foreign, do not suffer adverse consequences (Waghorne, 2003). They call for governments to ratify and respect workers' rights, including those of foreign workers covered by GATS. These rights must include the right to belong to a trade union and to use grievance procedures. In general, their concern is not so much that temporary employment could become permanent, but that the movement of workers could be used to undermine wages and working conditions.
} 
liberalization has been achieved, more active redistribution will be required to try to ensure that fewer nationals of developed countries are actually in sectors competing with foreign workers. This effort will require education and training as well as giving thought to asset distribution. However, these difficulties are neither more nor less serious than those posed for less skilled workers by imports of labor-intensive goods from developing countries - a problem overcome by policies to ease adjustment among local less skilled workers in developed countries. Applied with the same sensitivity and the same sorts of policies that trade policy reform in goods has received in the past, the temporary movement of less skilled workers between countries would offer the chance to reap large gains from trade.

Any attempt to facilitate individual mobility must confront today's increased concerns about national security. Meaningful liberalization of mode 4 requires that security clearance be quick and reliable. The challenge politically is to separate the security arguments from labor market or service export considerations. As Winters et al. (2001) note, even national security has a finite price in terms of civil liberty and economic well-being. Economic efficiency does not require one to neglect security considerations, but to ensure that if tradeoffs are made between security and income at one rate in one area - say, the maintenance of armed forces - then tradeoffs should be made at the same rate in another area - say, the exclusion of foreigners from national territory.

Finally, the concerns of home countries pertain primarily to the loss of skilled resources - a weaker version of the concern about the brain drain associated with migration. A full discussion of this issue is beyond the scope of this paper. But note that the key problem -ensuring an adequate social rate of return on public investment in human capital- can be addressed through appropriate tax and/or compulsory service policies even in a liberalized trade environment.

\section{SOME ECONOMIC AND POLITICAL CHANGES SINCE THE URUGUAY ROUND HAVE CREATED}

\section{EXPECTATIONS OF A MORE LIBERALIZING OUTCOME ON MODE 4}

During most of the Uruguay Round, mode 4 issues were framed - at least rhetorically —as differences between developed and developing countries (Self and Zutshi, 2003). The debate polarized countries unnecessarily and provoked a more defensive posture by both sides. Developed countries feared that they would be pressed to make politically unsustainable concessions at lower skill levels, and developing countries that placed a premium on this issue did nothing to assuage these fears.

At the same time during the Uruguay Round, few stakeholders pressed their interests upon their own governments as well as on others, with some notable exceptions. The Indian National Association of Software and Service Companies (NASSCOM) actively and effectively devoted time and resources to persuading countries to make commitments affecting software engineers. In the United States, a powerful and diverse lobby used the GATS negotiations to generate a U.S. binding of the H1B visa provision covering the temporary employment of highly skilled foreign workers in U.S. firms.

Since the Uruguay Round, many countries have undertaken a more comprehensive assessment of their needs in the area of temporary entry and stay. Indeed, today more stakeholders are active in both developed and developing countries. In an increasingly globalized world, firms need to be able to deploy personnel for short periods to meet specific project and contract requirements in different countries, often with tight deadlines. But they are frustrated by visa procedures that can delay entry of personnel by months. To remedy these problems, the U.S. Coalition of Services Industries and the European Services Forum have both endorsed improved mode 4 commitments by all countries to expedite the movement of professional-level personnel. The emergence of mode 4 as a strategic component of efforts to provide services in a large number of countries contrasts sharply with the environment in the Uruguay Round. 
A question that has not been fully explored is how the demands created by aging populations and shortages of skilled workers in developed countries will play out against the greater security concerns in a post-September 11 world. In any case, there does seem to be a coincidence of interest in the movement of skilled workers among developed countries and a set of more advanced developing countries. The greater challenge is to draw in other developing countries by venturing down the skill ladder without sinking into the realm of political infeasibility.

\section{The GATS and Mode 4}

In this Section we describe the lack of clarity in the GATS framework and the sad state of existing access commitments.

\section{GATS MODE 4 IS AMBITIOUS IN SCOPE BUT UNCLEAR IN DEFINITION}

There are at least three dimensions to the movement of an individual from one country to another for economic reasons: the length of stay, the level of skills, and the nature of the contract. Each dimension allows for significant variation. An individual can move for a single day or migrate permanently, possess no professional skills or be the master of a particular field, move as an independent professional or be transferred from headquarters to a local branch. The legal and economic implications of each type of movement are different.

What precisely is covered by mode 4 ? The answer is to be found in the Annex on Movement of Natural Persons Supplying Services under the Agreement. Two categories of measures are covered: those affecting "service suppliers of a Member" of the GATS (i.e., self-employed suppliers who obtain their remuneration directly from customers) and those affecting the natural persons of a member who are "employed by a service supplier of a Member, in respect of the supply of a service." The Annex also states that the GATS does not apply to measures affecting individuals seeking access to the labor market of a member country, or to measures regarding citizenship, residence, or employment on a permanent basis.

So nothing in the GATS limits the scope of natural persons to particular levels of skill, but the agreement is less clear on other dimensions. It has become customary to speak of the GATS as covering the temporary movement of service suppliers. But how long is temporary? The Agreement draws no clear lines, beyond the exclusion of permanent migration, and this issue is left to the discretion of individual countries. Thus, Japan allows foreign business travellers to stay for a maximum of 90 days, but certain categories of intra-corporate transferees can stay as long as five years. Such flexibility is an advantage of not creating a definitional straight-jacket. But the seemingly open-ended notion of temporary may render more difficult a credible distinction between mode 4 and migration - a distinction that could have provided significant political reassurance.

It is also not completely clear as to what types of contracts are covered. It would appear that measures affecting an Egyptian accountant's ability to sell his services abroad, either as an independent consultant or as an employee of an accounting firm, would be covered by the GATS. But do natural persons "employed by a service supplier of a Member" include foreigners employed only by foreign firms or also those employed by host country firms (e.g., an Egyptian accountant employed by a U.S. firm in the United States)? In so far as foreigners seeking employment with host country firms can be deemed to be accessing the labor market of a country, they would seem to fall outside the scope of the GATS. It has been suggested that this is a sensible delineation and to argue otherwise would provoke opposition and undermine the prospects of even more limited liberalization. On the other hand, the exclusion could 
create some economic distortions; a service delivered by a foreign worker under an employment contract to a local provider may be treated differently from the same service provided by the same person acting as an unattached service provider, say under a consultant contract. Such a distinction would channel into one form of service delivery transactions that ideally should take another form (Winters et al. 2001).

\section{MODE 4 HAS SO FAR ELICITED LIMITED COMMITMENTS THAT DO NOT EVEN REFLECT EXISTING}

\section{NATIONAL REGIMES}

Most existing commitments under the GATS pertain to business travelers and intra-corporate transferees who must be managers, executives, or specialists (Table 1). Such commitments are of limited interest to countries that are not significant foreign investors. Moreover, commitments are often qualified by other restrictions: prior employment, numerical quotas, economic needs tests, and residency requirements. It is widely acknowledged that WTO members' mode 4 commitments generally do not even reflect prevailing entry conditions for natural persons, because members have committed to less than the access granted in practice.

Table 1: Types of natural persons supplying services (horizontal commitments), April 2002

\begin{tabular}{|c|c|c|c|c|}
\hline & & $\begin{array}{l}\text { No. of } \\
\text { entries }\end{array}$ & $\begin{array}{l}\text { No. of } \\
\text { aggregate } \\
\text { entries }\end{array}$ & $\begin{array}{c}\% \text { of aggregate } \\
\text { entries }\end{array}$ \\
\hline \multirow{4}{*}{ 焉苟离 } & Executives & 56 & \multirow{4}{*}{168} & \multirow{4}{*}{$42 \%$} \\
\hline & Managers & 55 & & \\
\hline & Specialists & 56 & & \\
\hline & Others & 1 & & \\
\hline \multicolumn{2}{|c|}{ Executives } & 24 & \multirow{3}{*}{110} & \multirow{3}{*}{$28 \%$} \\
\hline \multicolumn{2}{|c|}{ Managers } & 42 & & \\
\hline \multicolumn{2}{|c|}{ Specialists } & 44 & & \\
\hline \multirow{2}{*}{ 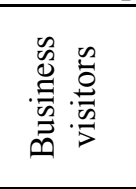 } & $\begin{array}{c}\text { Commercial } \\
\text { Presence }\end{array}$ & 41 & \multirow{2}{*}{93} & \multirow{2}{*}{$23 \%$} \\
\hline & $\begin{array}{c}\text { Sale } \\
\text { Negotiations }\end{array}$ & 52 & & \\
\hline \multicolumn{2}{|c|}{ Contract Suppliers } & 12 & 12 & $3 \%$ \\
\hline \multicolumn{2}{|c|}{ Other } & 17 & 17 & $4 \%$ \\
\hline \multicolumn{2}{|c|}{ Total $^{\mathrm{a}}$} & 400 & 400 & $100 \%$ \\
\hline
\end{tabular}

a Total number of entries by those WTO Members that have included commitments on Mode 4 in the horizontal section of their schedules.

Source: World Trade Organization

No significant differences exist between the commitments scheduled by developed and developing countries; both groups seem to have been equally hesitant in undertaking liberal commitments for mode 4 . But countries that acceded to the WTO after 1995 have been more willing to make commitments for "contract suppliers" (i.e., employees of a foreign enterprise that has concluded a contract to supply a service in a country but does not have a commercial presence in that market). 
In fact, it is difficult to map mode 4 against existing migration categories for temporary entry (Nielson and Cattaneo, 2003). Even in the context of highly detailed, state-of-the-art migration systems, like Australia and the US, problems have arisen in identifying the precise regimes relevant to mode 4. For example, although temporary and permanent entrants are separated, no distinction is made in migration categories between service and non-service activities. Nor is it always possible to judge whether the activities covered by some visa categories are truly commercial (i.e., that they would constitute trade for GATS purposes), while other categories include persons both consuming (mode 2) and supplying (mode 4) services.

Notwithstanding these difficulties, systems for temporary entry in many countries are broader, more detailed, and more flexible than their respective GATS commitments (Nielson and Cattaneo, 2003). Actual trade under mode 4-and numbers of temporary entrants - is also much greater than the commitments would suggest. Temporary entry is increasing for several countries, but is directed toward those with high level of skills or education. Several countries - Australia, Canada, France, Germany, United Kingdom - have recently taken initiatives to facilitate the entry of high skilled workers. Special facilitation or entry schemes are also being offered to nationals of certain countries, including on the basis of regional trade agreements (Nielson, 2003). But countries still require sponsored workers to be paid the same rates as nationals and to benefit from the same working conditions, and use a range of measures to limit any possible negative impact on nationals.

Several European countries have programs for less skilled, short-term foreign workers - for example, seasonal workers in agriculture, tourism, and the hotel trade; project workers in construction; and various other employment-specified workers (Winters et al., 2001). Several reasons are suggested for why these programs have not been included in the GATS commitments. One is that these schemes are often implemented on a bilateral basis (e.g., with Eastern and Central European and North African countries) to mitigate immigration pressures and therefore would not necessarily comply with the non-discrimination obligation of the GATS. The other reason is that a GATS binding may deprive the host countries of the flexibility with which the schemes are currently implemented. These issues are examined further in the final section.

Generally, preferential agreements among countries enjoying geographic proximity and similar levels of development (e.g., the European Union [EU], the European Free Trade Association [EFTA], the European Economic Area [EEA], Trans-Tasman Travel Arrangement between Australia and New Zealand) have a more liberal approach to labor mobility as compared with agreements among geographically distant members of differing levels of development (e.g., the Asia Pacific Economic Cooperation forum [APEC], U.S.-Jordan) (Nielson, 2003). ${ }^{5}$ Interesting examples of liberalizing NorthSouth accords are the North American Free Trade Agreement (NAFTA) and the recent agreements between the US and Chile and Singapore, respectively. The relevant aspects of some of these agreements are discussed in Section III.

\section{Looking Ahead: A Possible Approach to the Liberalization of Mode 4 in the Current Negotiations}

How can we take advantage of the liberal provisions in existing national regimes, regulatory innovations in regional agreements, and the more benign political climate to develop a framework for liberalizing commitments? Greater openness cannot be thrust upon governments. The question is then: Can governments develop certain instruments that facilitate an exchange of access commitments and define an acceptable set of multilateral rules that lead to more transparent and less burdensome policy?

\footnotetext{
${ }^{5}$ The former set of agreements typically seek deeper integration and not just the liberalization of trade.
} 
A model schedule is proposed as a basis for negotiations on mode 4. This schedule builds on the one contained in Hatcher (2003) that was endorsed also by the U.S. Coalition of Services Industries and the European Services Forum. The model is designed to supplement and improve the existing commitments WTO Members have undertaken in the Uruguay Round and the extended negotiation. Consequently, categories like longer-term intra-corporate transferees at higher levels and business visitors that are already part of most countries existing schedules, are not repeated. Depending on the extent of support for the "model schedule", it could be serve either as a "formula" of commitments that all Members are to assume, or as a focal point designed to generate improved commitments.

The schedule is presented in Annex 1, but here we summarize the main elements. The schedule is divided into two parts. The first part deals with market access and national treatment commitments under Part III of GATS. It envisages commitments essentially for natural persons with professional skills on shortterm, intra-company visits (category 1) and short-term visits to fulfill contracts (categories 2 and 3 ). Short term is defined in each case as a stay of less than a year. For these two classes of movement the schedule proposes a Service Provider Visa (SPV) in order to separate procedures that affect temporary and permanent entry and therefore streamline those for temporary entry. ${ }^{6}$

The second part of the model schedule represents a set of additional commitments that would be made under Article XVIII of the GATS - like the "reference paper" in basic telecommunications. This part encompasses domestic regulatory obligations that would enhance the transparency of procedures and limit the trade-impeding impact of measures such as qualification requirements and procedures.

\section{ASSUMPtions Underlying THE Model SCHEdUle FOR MODE 4}

The following assumptions built into the model schedule are based on preliminary discussions with stakeholders in a number of countries, as well as an assessment of temporary migration regimes in various countries. They represent a first step at defining the level of commitments that would imply substantial liberalization without being deemed politically infeasible. There is, nevertheless, a need to conduct wider consultations to test the validity of these assumptions.

Assumption 1. The emphasis should be on broad horizontal commitments assuring a basic minimum level of access across all sectors, supplemented by sector specific commitments where deeper liberalization is possible.

Existing obligations by nearly all WTO Members in the category of temporary entry of natural persons are structured to apply to all services sectors, and are therefore entered as "Horizontal Commitments" that apply to all sectors listed in their schedules of specific commitments. This follows the pattern of regulation in nearly all Members, where government measures governing the temporary entry of natural persons generally apply to all sectors. This model schedule follows the same structure, thus envisioning further entries in horizontal commitments pertaining to all sectors. ${ }^{7}$

\footnotetext{
${ }^{6}$ The basic idea has been elaborated before, both in the negotiating proposal by the Government of India and in the model schedule approach endorsed by the service industry bodies of the United States and the European Union.

${ }^{7}$ Where horizontal commitments must be qualified, this would ideally be on the basis of a narrow negative list of exclusions rather than through a limited positive list of included sectors (e.g. in the EU's draft offer).
} 
The main reason for this position is that horizontal commitments applying across all sectors would be easier to administer, especially for immigration authorities. As we saw above, few countries have sectoral categories in their immigration laws, and even distinguishing between service providers and others has proved difficult. Interviews with immigration authorities suggest that administering sector-specific commitments would be procedurally burdensome. And getting "buy-in" from immigration authorities is vital for the success of this approach. ${ }^{8}$

But the emphasis on horizontal commitments does not exclude the possibility of sector specific commitments specifying deeper levels of liberalization. This issue is closely related to the issue of the appropriate skill threshold. The underlying presumption in the basic model schedule is that commitments are assumed for skill levels above a certain skill threshold, and that such a standard exists in virtually every service sector. In fact, most regimes (and current offers) typically require professional qualifications or a bachelors degree as a minimum, reflecting the unwillingness of most countries to countenance liberal entry of lower skilled people (Table 2). However, in certain sectors, countries may be willing to accept lower skill thresholds, e.g. diplomas rather than bachelors degrees for software programmers. To exploit these possibilities, there must remain the possibility of more liberal sectorspecific commitments.

Assumption 2. Employment-based movement is a less fruitful subject for multilateral negotiations than intra-corporate movement and the presence of natural persons to fulfill service contracts.

Figure 1 depicts the options for international movement of professionals. The first class of movement involves the Indian professional working for a US based-firm - which could be of US, third country or Indian origin. If the professional were already employed in India by the same firm, then he/she would be an intra-corporate transferee. The other broad class of movement is contract-based, where the professional does not work for a US-based firm but moves to fulfill contracts obtained from the final consumer. This class of movement can involve independent professionals or employees of India-based firms. These classifications are convenient but the distinctions are sometimes blurred as we shall see below.

\section{EMPLOYMENT-BASED MOVEMENT}

Employment-based movement is undoubtedly important. In fact, entry into the United States, is generally only possible if there is a prior offer of employment with a US-based firm - under the specialty occupations provision $(\mathrm{H}-1 \mathrm{~B})$ - or as an intra-corporate transferee.

The US and Australia are among those who have included the category of employment-based movement in their recent GATS offer in an unchanged form from their GATS schedules. The US commitment is to permit individuals with highly specialized knowledge an initial stay of three years, under the H1-B program. The worker must be professionally qualified, i.e., have a US bachelor's degree or its equivalent and be offered a skilled job position related to the worker's professional background. The worker must obtain full licensure in a U.S. state to practice the occupation, if such licensure is required by a condition application" state. A key requirement is that the petitioning US employer must meet "labour (LCA)

\footnotetext{
${ }^{8}$ With regard to migration authority buy-in, we must also consider how a SPV visa might be combined with existing migration and visa regimes. On the one hand, those countries most likely to have the resources to implement it are also those who are likely to already have a more detailed scheme in place. They may be reluctant to wind these schemes up and use the SPV instead. On the other hand, the SPV might be onerous for some developing country migration authorities to implement. As mode 4 trade is not simply into developed countries, this angle should perhaps be considered. Some countries also prefer to limit visa procedures in the interests of minimizing their drain on scarce administrative resources (e.g., South Africa).
} 
Table 2: Comparison of Mode 4 Offers and Regimes

\begin{tabular}{|c|c|c|c|c|c|}
\hline & US offer & EU offer & Canadian offer & Australian offer & Additional coverage in Model Schedule \\
\hline $\begin{array}{l}\text { Intra- } \\
\text { corporate } \\
\text { transferees }\end{array}$ & $\begin{array}{l}\text { Managers, executives, and } \\
\text { specialists allowed an initial stay of } \\
3 \text { years with no mention of an } \\
\text { economic needs test under the L-1 } \\
\text { program. } \\
\text { Entry may be extended for up to } 2 \\
\text { additional years for a total term not } \\
\text { to exceed } 5 \text { years. } \\
\text { Note: Currently, managers and } \\
\text { executives (L1-A) can extend their } \\
\text { stay up to a total of } 7 \text { years, while } \\
\text { specialists (L1-B) can do so up to a } \\
\text { total of } 5 \text { years. }\end{array}$ & $\begin{array}{l}\text { Managers and specialists } \\
\text { admitted for an initial period } \\
\text { of } 3 \text { years with no economic } \\
\text { needs test. } \\
\text { Graduate trainees } \\
\text { admitted for a period of } 1 \\
\text { year with no economic } \\
\text { needs test. }\end{array}$ & $\begin{array}{l}\text { Managers, executives, and } \\
\text { specialists to be admitted on } \\
\text { being granted a work } \\
\text { permit, for an initial period } \\
\text { equivalent to the period of } \\
\text { transfer, with the } \\
\text { possibility of extensions, } \\
\text { provided the temporary } \\
\text { residency status is } \\
\text { maintained and } \\
\text { demonstrated. } \\
\text { In the case of specialists, } \\
\text { entry and stay, including } \\
\text { extensions, may not exceed } \\
\text { five years. } \\
\text { There is no requirement of } \\
\text { labor market tests for } \\
\text { qualifying intra-corporate } \\
\text { transferees, and their } \\
\text { spouses and common law } \\
\text { partners. }\end{array}$ & $\begin{array}{l}\text { Executives and senior } \\
\text { managers admitted for an initial } \\
\text { period of up to } 4 \text { years with no } \\
\text { mention of an economic needs } \\
\text { test. }\end{array}$ & $\begin{array}{l}\text { Employees of a company or a partnership } \\
\text { who provide assistance, advice, a service to } \\
\text { a foreign client, or receive training in } \\
\text { business techniques and methods should be } \\
\text { admitted for a maximum of } 1 \text { year with no } \\
\text { economic needs test. }\end{array}$ \\
\hline $\begin{array}{l}\text { Employees of } \\
\text { host based } \\
\text { firms }\end{array}$ & $\begin{array}{l}\text { Specialists with at least a U.S } \\
\text { bachelors degree (or its equivalent) } \\
\text { and highly specialized knowledge } \\
\text { allowed an initial stay of } 3 \text { years } \\
\text { under the H1-B program. } \\
\text { Specialty occupation employers } \\
\text { must be in compliance with all labor } \\
\text { condition application requirements } \\
\text { such as a) prevailing wage, b) no } \\
\text { adverse effect on working } \\
\text { conditions of similarly employed, c) } \\
\text { no strike/lock out in the course of a } \\
\text { labor/management dispute in } \\
\text { progress at the place of employment, } \\
\text { d) no layoffs for the position within } \\
\text { a } 6 \text { month period prior to or } 90 \text { day } \\
\text { period after the petitioning of a } \\
\text { foreign worker, and e) timely and } \\
\text { significant steps taken to recruit and } \\
\text { retain sufficient US workers for the } \\
\text { position. }\end{array}$ & & & $\begin{array}{l}\text { Specialists with trade, technical } \\
\text { or professional skills, subject to } \\
\text { individual compliance with } \\
\text { labor market testing, are } \\
\text { allowed an initial stay up to a } \\
\text { maximum of } 2 \text { years, with } \\
\text { provision of extension provided } \\
\text { the total stay does not exceed } 4 \\
\text { years. } \\
\text { Labor market testing is waived } \\
\text { if the individual a) has a } \\
\text { specialized knowledge at an } \\
\text { advanced level of a proprietary } \\
\text { nature of the company's } \\
\text { operations and has been an } \\
\text { employee of the company for at } \\
\text { least } 2 \text { years, and b) if the } \\
\text { position in question is within in } \\
\text { a labor agreement in force at } \\
\text { the time of application. }\end{array}$ & \\
\hline
\end{tabular}


Note: Currently, H1-B visa holders

can extend their stay up to a

maximum of 6 years. New

legislation requires $\mathrm{H} 1-\mathrm{B}$ dependent

employers to advertise positions in

the US before petitioning a foreign

worker.

\section{Contractual \\ service}

supplier



Employees of a juridical

person, on a contract that has been tendered or advertised, admitted for a period not exceeding 6 months in any 12 month period, with no mention of an economics needs test.

Commitments are subject to the application of a numerical ceiling, except where otherwise indicated, for a particular sub-sector.

Commitments apply to a specific list of professions.

\section{Independent professionals,} practicing as self-

employed, on a contract

that has been tendered or

advertised, admitted for a

period not exceeding 6

months in any 12 month

period, with no mention of

an economic needs test.

Commitments are subject to the application of a numerical ceiling, except

where otherwise indicated, for a particular sub-sector.

Commitments apply to a specific list of professions.
Professionals, seeking to

engage as part of a services

contract granted by a

juridical person or a service

consumer in Canada and

obtained by a juridical

person or a service supplier

of another WTO member, to

be admitted on being

granted a work permit for

an initial stay of 1 year, or

the time necessary to

complete the contract,

whichever is less, and

extensions are possible.

No labor market test

required for qualifying

professionals, and their

spouses and common law

partners.

Commitments apply to a

specific list of professions.

There will be a limit of 10 entrants per project in the

case of senior computer

specialists.

Professionals must possess the necessary academic

credentials and professional

qualifications, which have

been duly recognized, where

appropriate, by the

professional association in

Canada.
Employees of a juridical person should be admitted for short periods of stay up to a maximum of 1 year.

Independent professionals should be admitted for short periods of stay up to a maximum of 1 year.

Source: Compiled by authors from WTO documents and national websites. 


\section{Figure 1}

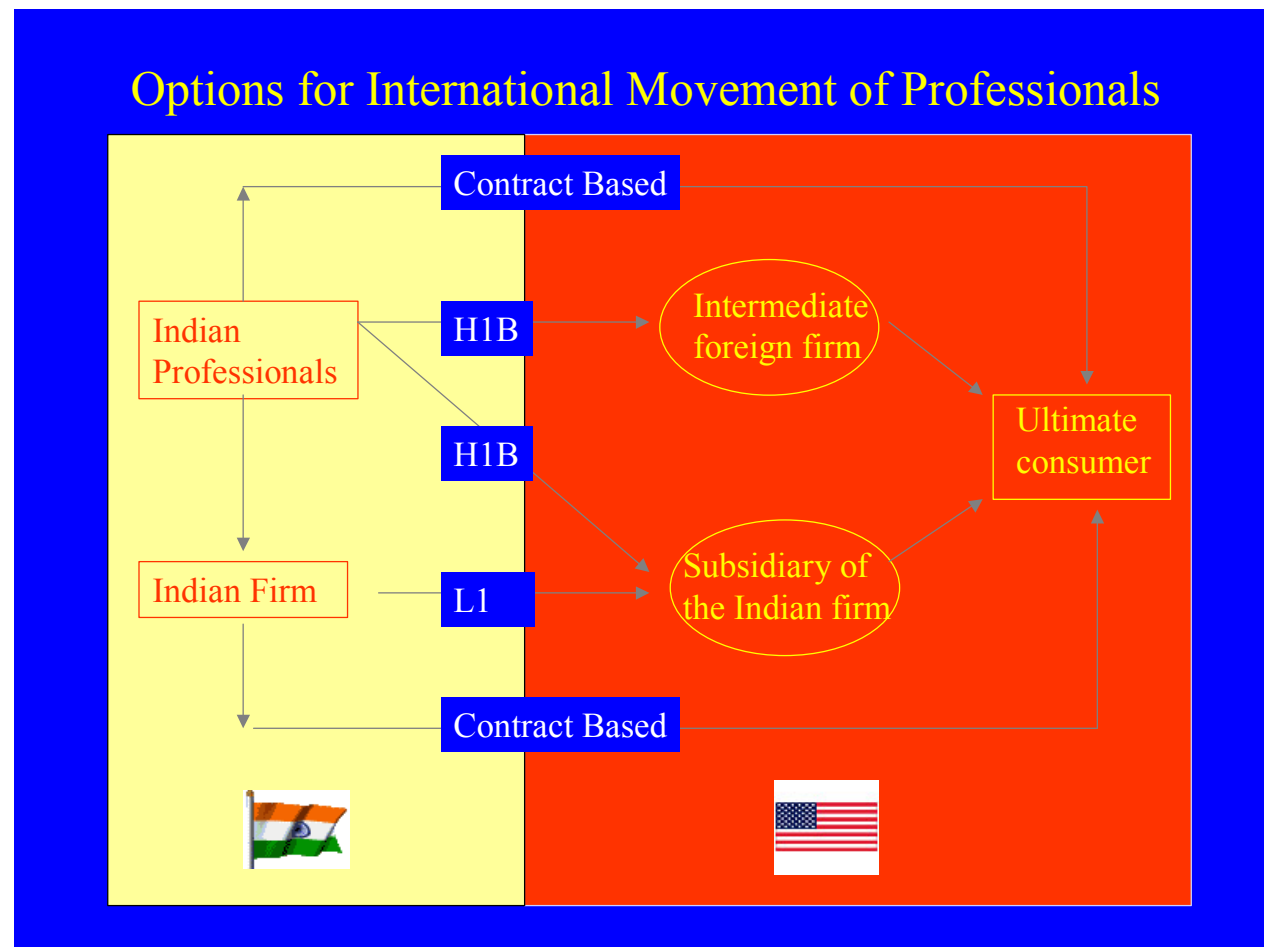

Note: The H1B visa category in the United States involves employment-based movement whereas the L1 category involves intra-corporate movement.

requirements: the employer must pay at least the prevailing wage; there should be no adverse affect on working conditions for those similarly employed; there must be no strike/lockout in progress at the place of employment affecting the subject occupation, and no layoffs from the position within a 6 month period prior to or 90 day period after the petitioning of a foreign worker; and the US employer should have a record of attempting to recruit and retain sufficient US workers in the specialty profession. ${ }^{9}$

In practice, H1-B workers can stay for an initial period of three years as committed, but can extend their stay for a maximum of six years. There is an annual cap on the number of approved H1-B petitions totaling 195,000 for the 2001-2003 fiscal period, but in the absence of new legislation, the cap will revert to only 65,000 from 2004 onwards. Furthermore, new H1-B legislation requires H1-B dependent employers in the US to advertise positions in the US before petitioning an H1-B worker.

It is interesting to note that even the regional and bilateral agreements involving the US -NAFTA, USChile and US-Singapore - only allow for employment-based movement for professionals though in each case movement has been facilitated by the creation of a special streamlined visa. The skill threshold in each case is a bachelors degree or equivalent. In NAFTA, only Mexican professionals were subject to a temporary annual quota of 5,500 which expired on 1 January 2004, while Chilean and Singaporean

\footnotetext{
${ }^{9}$ Australia's offer is similar, except that the initial stay is limited to two years. Australia requires the business sponsor of the foreign worker to demonstrate, amongst other things, that Australia will benefit from the business employing overseas personnel (e.g., by creating or maintaining employment for Australia, expanding trade in goods and services, improving business links with international markets, or increase competitiveness with certain sectors), that the sponsor will advance skills through technology or training, and that it will offer a specified minimum salary.
} 
professionals are subject to an annual quota of 1,400 and 5,400 respectively. ${ }^{10}$ The caps on the latter two countries are unlikely to be binding if the number of annual H-1B visas issued to each last year (around 250 to Chile and 600 to Singapore) is any indicator of future demand. The key element in all of the three previously mentioned agreements is the retention of the LCA described above, with its wage parity requirement -strongly supported by US labor interest groups. ${ }^{11}$

For several reasons, some of which are further elaborated below, the model schedule does not include employment-based movement. First of all, until recently, the H-1B category has worked less as a temporary migration scheme than as a selective permanent migration scheme,. Lowell (2000) suggests that a substantial proportion of $\mathrm{H}-1 \mathrm{~B}$ entrants adjust from the temporary visa to permanent resident status but the precise number is difficult to estimate. In practice, it is as if the employing firm performs a screening function, putting forward selected foreign employees for permanent resident status. As noted above, the benefits of permanent migration are less clear than those of temporary migration for home countries. In any case, the demand for foreign employees is likely to be determined by domestic economic conditions and, as in the US, a large number of domestic firms can be relied on to push for increased access.

\section{INTRA-CORPORATE MOVEMENT}

Intra-corporate movement is already one of the most liberal categories within mode 4, but most existing commitments pertain only to managers, executives and specialists. Traditionally, this is a form of movement of greatest interest to developed country multinationals. But interestingly the emergence of IT, audiovisual, and construction multinationals implies that developing countries like India and Brazil also have a strong interest in intra-corporate movement, especially when it pertains not just to the category of specialists but a wider group of professionals. Interviews with Indian firms based in the US confirm the view that the L1 visa is an important but increasingly stringent category. For example, the Infosys annual report for 2002 states, "As of March 31, 2002, the majority of our personnel in the United States held H-1B visas (1,582 persons) or L-1 visas (445 persons)” (Hira 2003).

Most countries' current offers include the same categories of persons, namely managers, executives, and specialists. The duration of initial stay permitted varies from about three years in the US, EU and Canada to four years in Australia. In each case intra-corporate transferees are exempt from an economic needs test, provided the person has been in the prior employment of the firm for a period of at least a year. There are no quotas and also no requirement of wage parity. ${ }^{12}$

\footnotetext{
${ }^{10}$ The Chile and Singapore quotas were apparently not additional to, but part of the overall H1B quota - raising concerns about their consistency with the US GATS commitment to allow 65000 entrants on an MFN basis.

${ }^{11}$ While the texts of all three agreements state that "no party shall as a condition for temporary entry of professionals, require prior approval procedures, petitions, labor certification tests or other procedures of similar effect", they also state that "a party may require the business person to comply with procedures applicable to temporary entry of professionals, such as an attestation of compliance with the party's labor and immigration laws". Under NAFTA, Mexican nationals are required to have their prospective employer file an LCA to qualify for the TN visa, while Canadian workers are not (see the State Department website http://travel.state.gov/tn_visas.html for details). In a follow-up communication to Chile, it was stated that "The US intends to implement its requirement for a labor attestation in a manner similar to the current Labor Condition Application (LCA) required under its H1-B program." Similarly, in the US-Singapore FTA, the US has reserved the right to impose the LCA requirement.

${ }^{12}$ A look at the actual regimes indicates that the US imposes neither prevailing wage requirements, nor annual caps on approved petitions for this visa category. Moreover, managers and executives can extend their US stay up to a period of 7 years, while specialists can do so up to a period of 5 years.
} 
The model schedule lowers the bar on intra-corporate transferees by advocating temporary entry of up to a year for a wider category of employees who provide assistance, advice or service to a foreign client, or receive business training, irrespective of their place in the organizational hierarchy. Furthermore, there is no requirement of a period of prior employment. The key point is that where firms have a commercial presence abroad, the proposed intra-corporate route - liberated from quotas, wage-parity and other burdensome requirements - may be a more efficient way of servicing foreign markets than by seeking new employment-based movement. The scope for exploiting this avenue would be greatly enhanced if intra-corporate movement were defined to include a wider class of skilled employees as in the model schedule.

There is bound to be political opposition to the lowering of the threshold for intra-corporate movement. Concern has already been expressed in the United States about the subsidiaries of Indian firms bringing in lower skilled workers on the L1 visa not subject to the LCA. But if this pressure can be resisted, then a wider liberalizing dynamic could be created: domestic firms, that face even greater competition from foreign multinationals able to employ foreign employees unconstrained by a wage parity condition, would push for greater employment-based movement.

\section{CONTRACTUAL SERVICE PROVIDERS}

The other categories included in the model schedule pertain to natural persons who move to fulfill services contracts. This type of movement, like employment-based movement, is attractive for developing countries because it is not contingent on commercial presence in the host country. The assumption here is that in the current services negotiations, it may be more fruitful to focus on the strictly temporary movement of natural persons to fulfill prior service contracts. This implies deepening and generalizing the EU's contract-based offer rather than the US's H-1B employment-based offer (both are available from the WTO website).

There are two main reasons why a negotiating focus on a contract-based approach may be preferred, relating respectively to its greater desirability and feasibility. First, contract-based movement is more likely to be temporary than employment-based movement. If the movement is temporary, then we can be fairly confident that both the host and home country will gain. The benefits of permanent migration are less clear: the gains from remittances, networks, investment, etc. must be weighed against the possible costs of "brain drain." Second, it may be easier to seek more liberal access on strictly short-term contractbased movement through trade negotiations than on longer-term employment-based movement. The former is more closely identified with trade in services per se while the latter is seen as a direct entry into the labor market and likely to be determined by the needs of economies for such type of movement.

The greater feasibility of contract-based movement itself has two implications. First, it may be easier to create a separate fast-track non-immigration visa category for strictly temporary contract-based movement than for employment-based movement. Hence, the suggestion for a "service provider visa" in the model schedule. Second, it may be easier to liberate contract-based movement from economic needs tests (e.g. in the EU offer) and wage-parity requirements (e.g. in the US offer). Hence, the provision in the model schedule to eliminate both for contractual movement.

One key question must be addressed: is there a meaningful difference between "employment contracts" and "services contracts"? The following advice from Work Permits (UK), a website that provides information on how work permits may be obtained in the United Kingdom, helps clarify the distinction:

"As recruitment agencies are not able to sponsor work permits, the Work Permits (UK) are particularly meticulous in scrutinizing applications for candidates who will be working on client projects - especially where the work will occur at client sites. In order for you to obtain a work 
permit for a candidate who will be working at a client's offices, you must demonstrate that you are providing a service for which you have project responsibility rather than simply providing people. In order to prove this, you will need to produce a signed copy of your contract with the client." (emphasis added)

And:

"If your client's requirement can be turned from internal works into a defined outsourced project comprising of identified work parcels/responsibilities that are then handled to a recognized solutions provider, then that solutions provider can employ the candidate."

It must, nevertheless, be acknowledged that a distinction between employment and contract-based movement will be difficult to enforce. In some professions, e.g. architecture, it is possible to conceive of a well-defined task that can be sub-contracted and the completion of the task is observable. In other professions, e.g. nursing, such lines are difficult to draw, and the fulfillment of the contract will have to be linked to the completion of a period of service - hence the suggested maximum duration of one year, or any other period that a country deems appropriate.

The EU and Canada offers (and existing schedules) have a special category for temporary entry by contractual service suppliers (Table 2). The EU makes a distinction between contractual service suppliers who are employees of firms based abroad and those who are independent professionals, but Canada does not. While the EU allows contractual providers entry for a maximum of six months, Canada permits entry and stay for an initial period of one year or the time necessary to complete the contract. The EU schedule specifies the services that can be provided in this manner, and the list is substantially shorter for independent service providers (Table 2). Canada commits to only nine categories of professionals. ${ }^{13}$ The EU reserves the right to apply numerical ceilings while Canada does so only for senior computer specialists, where there is a limit of 10 entrants per project. $^{14}$

The model schedule also advocates admitting both employees of juridical persons and independent professionals for up to a year but there are important differences with the EU offer worth noting.

i. Under the new EU offer, foreign service providers are eligible to fulfill only those contracts that are subject to a tendering procedure, or at least advertised. The model schedule imposes no such conditions.

ii. The duration of stay for contract-visa workers under the new EU offer is a maximum of 6 months in any given year (an improvement over the 3 months in its Uruguay Round schedule). The model schedule proposes a maximum stay of a year for this category of employees.

iii. The EU offer covers a limited set of professions (expanding the list in the original EU schedule) that is narrower for independent service providers than for employees (Table 3). The model schedule proposes coverage of all service sectors.

\footnotetext{
${ }^{13}$ Engineers, agrologists, architects, forestry professionals, geomatics professionals, land surveyors, foreign legal consultants, urban planners and senior computer specialists.

${ }^{14}$ The actual regimes in certain countries may be more liberal than the EU commitments in certain respects. For example, a non-France based foreign company, with the cooperation of its French client, can use the 'temporary secondment' visa to place their employees on its client's site in France for up to a maximum of 18 months and this may then be extended for a further 9 months rather than for just the 6 month period listed in the EU commitments.
} 
iv. EU commitments are subject to numerical ceilings, and in the case of France an economic needs test. Both the needs test and the numerical ceilings are waived in the model schedule.

v. Finally, the EU offer does not contain any provision for a special visa category or additional regulatory commitments of the kind proposed in the model schedule.

A wider gap exists between the model schedule and the US's H-1B employment-based offer. The U.S. regime severely conditions contract-based movement through labor market tests and wage parity requirements. Even in the relatively unthreatening context of regional agreements with Chile and Singapore, such conditions have not been relaxed. The main reason is the insistence by US labor interests that the Labor Condition Application (LCA) - including its wage-parity requirement - be an integral part of any international agreement, and the perception that such a condition can only be effectively policed in the context of an employment contract. In a sense, it is rational for labor interests to be less concerned about the length of time for which an individual foreign worker/provider is present than the price at which he/she sells his service. Dealing with these concerns, and overcoming this resistance, is perhaps the greatest hurdle to the liberalization of mode 4 under the GATS.

Assumption 3. It will be necessary to have additional commitments on transparency and domestic regulation.

First of all, in recognition of the fact that ignorance and unpredictability are themselves a major impediment to mode 4 trade, it would seem desirable to improve the transparency of regulatory procedures. Existing GATS transparency rules, which simply require publication or public availability of measures, are not adequate. Valuable additional elements would require Members to make available, in a consolidated text, all measures that pertain to the temporary admission of natural persons; provide information on the materials or evidence required of an applicant seeking temporary admission into their territories; and grant approval of applications for temporary admission within a defined period of time. Furthermore, interested parties (including trading partners) would ideally be given an opportunity for comment prior to the introduction of any new measure or alteration of existing measures pertaining to the temporary movement under mode 4 . If this were to seem overly burdensome, then an alternative is to strengthen the existing system of ex post-notification to the WTO after the introduction of the measure.

We have seen that domestic regulations such as qualification requirements, licensing requirements and procedures, and technical regulations are a major impediment to mode 4 . The promise of national treatment is of considerable value because it would insure foreign professionals against de jure and de facto discrimination through regulatory measures. But discussions with professionals suggest that a nondiscrimination obligation is not enough because there is uncertainty about how it would be interpreted in the regulatory context, and, in any case, it would be costly to enforce. There is great support, however, for mutual recognition agreements. While such agreements are undoubtedly the most effective means of ensuring liberal access, they require a degree of regulatory convergence that is rare (e.g. even within the EU) and the incentives to conclude such agreements with developing countries are weak. It should nevertheless be possible to seek commitments from members that when they do conclude such agreements, they should follow the principles specified in the guidelines established for the accountancy sector. This may help prevent the discriminatory impact of mutual recognition agreements concluded with only a subset of trading partners. ${ }^{15}$

\footnotetext{
${ }^{15}$ One problem is that MRAs are frequently not between governments - which are subject to WTO obligations - but concluded by the relevant professional bodies.
} 
An alternative approach to regulatory impediments is based on Article VI of GATS. Given that the progress under Art. VI:4 is slow and the possibility of horizontal disciplines remote, the challenge is to induce Members to take additional commitments that achieve the broad objectives of this provision. The idea would be to introduce a hierarchy of measures, and the burden of proof would be placed on the regulator to justify the move from a less burdensome measure to a more burdensome one. There would be a presumption that administering a test of professional competence and/or educational attainment to verify the foreign professional's competence is the least burdensome measure. Only where it was necessary would a foreign professional be required to make up objectively verifiable deficiencies in their education, training and experience. However, we recognize that even though these proposals have a certain intuitive appeal, securing wider acceptance for them will not be easy. 
Table 3: Coverage of the EU's offer on contractual service providers in selected areas

\begin{tabular}{|c|c|c|}
\hline Service & $\begin{array}{l}\text { Commitments on } \\
\text { employees of } \\
\text { juridical persons }\end{array}$ & $\begin{array}{l}\text { Commitments on } \\
\text { independent } \\
\text { professionals }\end{array}$ \\
\hline \multicolumn{3}{|l|}{ 1. Professional services } \\
\hline Legal services & Yes & Unbound \\
\hline Accounting and book keeping services & Yes & Unbound \\
\hline Taxation advisory services & $\begin{array}{l}\text { Yes but unbound for } \\
\text { several EU countries }\end{array}$ & Unbound \\
\hline Architectural, Urban Planning and Landscape services & Yes & Yes \\
\hline Translation services & Yes & Yes \\
\hline Engineering services & Yes & Yes \\
\hline Medical and dental services & Unbound & Unbound \\
\hline Veterinary services & Unbound & Unbound \\
\hline Mid-wives, nurses, physiotherapists and para-medicals & Unbound & Unbound \\
\hline 2. Computer and related services & Yes & Yes \\
\hline 3. Research and development services & $\begin{array}{l}\text { Yes but unbound for } \\
\text { most EU countries }\end{array}$ & Unbound \\
\hline \multicolumn{3}{|l|}{ 4. Other business services } \\
\hline Advertising services & Yes & Unbound \\
\hline Market research and opinion polling services & Unbound & Unbound \\
\hline Management consulting and related services & Yes & Yes \\
\hline Technical testing and analysis services & Yes & Unbound \\
\hline Related scientific and technical consulting services & Yes & Unbound \\
\hline Maintenance and repair of equipment & Yes & Unbound \\
\hline 5. Communication services & Unbound & Unbound \\
\hline 6. Construction services & $\begin{array}{l}\text { Yes but unbound for } \\
\text { most EU countries }\end{array}$ & Unbound \\
\hline Site investigation work & $\begin{array}{l}\text { Yes but unbound for } \\
\text { several EU countries }\end{array}$ & Unbound \\
\hline 7. Distribution services & Unbound & Unbound \\
\hline \multicolumn{3}{|l|}{ 8. Education services } \\
\hline Primary, Secondary and Adult education services & Unbound & Unbound \\
\hline Higher education services & $\begin{array}{l}\text { Yes but unbound for } \\
\text { most EU members }\end{array}$ & Unbound \\
\hline 9. Environmental services & Yes & Unbound \\
\hline 10. Financial services & Unbound & Unbound \\
\hline 11. Health related and social services & Unbound & Unbound \\
\hline \multicolumn{3}{|l|}{ 12. Tourism services } \\
\hline Travel agencies and tour operator services & $\begin{array}{l}\text { Yes but unbound for } \\
\text { several EU members }\end{array}$ & Unbound \\
\hline \multicolumn{3}{|l|}{ 13. Recreational, cultural and sporting services } \\
\hline Entertainment services & $\begin{array}{l}\text { Yes but unbound for } \\
\text { most EU members }\end{array}$ & Unbound \\
\hline Sporting and other cultural services & Unbound & Unbound \\
\hline 14. Transport services & Unbound & Unbound \\
\hline
\end{tabular}


Table 4 summarizes the key element of the proposed model schedule.

Table 4: Barriers to Mode 4 and the Approach Proposed in the Model Schedule

\begin{tabular}{|l|l|}
\hline \multicolumn{1}{|c|}{ Type of Barriers } & \multicolumn{1}{|c|}{ Proposed Approach } \\
\hline Visa formalities & $\begin{array}{l}\text { Creation of a streamlined Service Provider } \\
\text { Visa (SPV) for intra-corporate and contract- } \\
\text { based movement of professionals for a period } \\
\text { of less than one year. }\end{array}$ \\
\hline $\begin{array}{l}\text { Quantitative restrictions (explicit or through } \\
\text { economic needs tests) }\end{array}$ & Prohibited by full market access commitments \\
\hline $\begin{array}{l}\text { Discrimination through internal measures } \\
\text { taxes and regulations) }\end{array}$ & Prohibited by national treatment commitments \\
\hline $\begin{array}{l}\text { Lack of transparency and predictability in in } \\
\text { regimes regulatory requirements }\end{array}$ & $\begin{array}{l}\text { Positive obligations requiring publication in } \\
\text { consolidated form of all pertinent measures, } \\
\text { and opportunity for prior comment on proposed } \\
\text { changes in regimes }\end{array}$ \\
\hline $\begin{array}{l}\text { Burdensome } \\
\text { pertaining to qualifications, etc. } \\
\text { standards where they exist, and tests of } \\
\text { competence where they do not. Only where } \\
\text { necessary would a foreign professional be } \\
\text { required to make up objectively verifiable } \\
\text { deficiencies in education, training and } \\
\text { experience }\end{array}$ \\
\hline
\end{tabular}

\section{Some qualifications to the suggested approach}

The proposed approach raises several concerns. First, the choice of the category of skilled professionals is politically convenient, but is it sufficiently ambitious? In economic terms, the largest global benefits will arise precisely from the greater movement of unskilled workers. Furthermore, unless the movement of unskilled and semiskilled workers is given parity of consideration along with the movement of persons with professional qualifications, many developing countries will be deprived of an opportunity to participate in the global provision of services, and will have less interest in these negotiations. However, venturing too far down the skill ladder may unfortunately undermine the political feasibility of the whole endeavor, because few countries are today willing to assume multilateral commitments on unskilled labor. Choosing a skill threshold that strikes the appropriate balance between economic gains and wider participation on the one hand, and political feasibility on the other, is perhaps the greatest challenge in the current negotiations.

The second concern, raised above, concerns the practical effects of the temporary entry provisions negotiated in international trade agreements. The special rules on temporary entry created by these agreements could, ironically, result in a burden for both immigration officers and business people. For example, some providers, instead of sailing smoothly through a port of entry, may be pulled out of the queue and directed to a secondary inspection area where immigration officers must interview them to ensure they comply with the special rules of trade agreements (Henry, 2003). This is why immigration authorities favor improved rules that are generally applicable. In fact, the descriptions of the (temporary) immigration regimes reveal that most do not treat mode 4 as a distinct category, raising a concern about how any future liberalization can be made compatible with Members' migration regimes. 
The private sector too seems to regard the GATS category as a somewhat artificial construct. For example, an Indian software engineer working for Credit Suisse in the United States falls within the scope of the GATS, whereas working for American Express in the United States may not, and working for General Motors does not. Would it, therefore, make sense to take a horizontal view of mode 4 to cover temporary movement regardless of whether the natural person is involved in services or goods production? If the WTO does extend its domain to investment in goods, should a symmetrical treatment of factors of production imply a wider view of mode 4 ?

A third concern is more fundamental: Could the GATS insistence on nondiscrimination and binding commitments actually inhibit liberalization in an area where there is a greater willingness to liberalize on a regional, preferential and cyclical basis, and where, in most cases, existing visa procedures are based upon reciprocity? The tension between bilateral or regional agreements and the most-favored-nation (MFN) principle is evident, and it has affected virtually all service sectors. To an extent, this tension is accommodated in mode 4 by flexibly applying the MFN principle to measures such as visa requirements. However, as with discriminatory regional trading arrangements, currently favored suppliers may be reluctant to support MFN liberalization if they feel that they have more to lose than to gain. The constraining effect of international binding commitments is noted by Henry (2003), who states that there is a preference in Canada for the general provisions of Canada's current immigration regime and the policymaking flexibility it allows. The general provisions are preferred because they can be used to respond to changes in the domestic labor market or economy, and because they allow for temporary and managed policy responses.

The question arises: are we likely to make greater progress in facilitating and managing movement through WTO "market access" based negotiations or through other forms of international cooperation? One possibility is that the WTO process of reciprocal liberalization will deal only with the temporary movement of the highly skilled service providers, where there is a coincidence of interest between the developed and the more advanced developing countries. But if the WTO requirements of nondiscrimination among trading partners and binding commitments may inhibit liberalization as we move down the skill ladder, then the movement of the less skilled could be the subject of bilateral cooperation agreements - designed to ensure temporariness and maximize the development impact of movement, e.g. through the management of remittances and reintegration in the home country. There might then be a case for exempting such agreements from the MFN obligation if they do not fulfill the conditions of Article V and Vbis on integration agreements. It is also essential to explore whether such bilateral cooperation, by helping to ensure compliance with host country conditions, can help produce a successful outcome in the WTO negotiations.

In any case, there is likely to be a greater willingness to make legally binding horizontal commitments on mode 4 in exchange for specific market access benefits. Devising such negotiating tradeoffs across sectors and modes will in fact be central not only to progress on mode 4 but also to the success of the whole services negotiations. In this context, the model schedule approach may provide useful suggestions on the conduct of mode 4 negotiations. They include: negotiating market access and national treatment commitments from a common template that is sufficiently flexible for parties with differing interests and varying levels of ambition; developing a set of agreed-on regulatory principles that would improve the transparency of procedures granting temporary entry to service providers; reaching an agreement on the skill levels of workers affected by the temporary entry negotiations, as part of the negotiating process itself; and enhancing collaboration between trade, immigration, and labor policy communities, and between officials from developing and developed countries. 


\begin{tabular}{|c|c|c|c|}
\hline Sector or subsector & Limitations on market access & \multicolumn{2}{|l|}{$\begin{array}{l}\text { Limitations on } \\
\text { national treatment }\end{array}$} \\
\hline \multicolumn{4}{|c|}{ I. HORIZONTAL COMMITMENTS } \\
\hline $\begin{array}{l}\text { All sectors: } \\
\text { Temporary entry and } \\
\text { stay of natural } \\
\text { persons }\end{array}$ & $\begin{array}{l}\text { 4) None for the following categories: } \\
\text { 1. Short-term, intra-company visits. This category covers: (1) } \\
\text { Employees of a company or a partnership who enter for short } \\
\text { periods of stay up to } 1 \text { year at its office in X to provide assistance } \\
\text { or advice or a service to a foreign client; and (2) Employees of a } \\
\text { company or partnership who are sent to its office in X for training } \\
\text { in business techniques or methods. } \\
\text { 2. Short-term visits by employees. Persons who are employees } \\
\text { of a foreign-based company or partnership, who travel to X for } \\
\text { short periods of stay, (1) up to } 1 \text { year, in order to perform a service } \\
\text { pursuant to a contract(s) between their employer and a client(s) } \\
\text { located in X where the employer does not have an affiliate office, } \\
\text { and where remuneration must be paid solely to the employer; and } \\
\text { (2) in order to fulfill qualification and licensing requirements, } \\
\text { where presence in X is an essential condition for the fulfillment of } \\
\text { these requirements. } \\
\text { 3. Short-term visits by independent professionals. Natural } \\
\text { persons who travel to X for short periods of stay, (1) up to } 1 \text { year, } \\
\text { in order to perform a service pursuant to a contract(s) between } \\
\text { them and a client(s) located in X and remuneration is to be paid } \\
\text { solely to the natural person; and ( } 2 \text { ) in order to fulfill qualification } \\
\text { and licensing requirements, where presence in X is an essential } \\
\text { condition for the fulfillment of these requirements. }\end{array}$ & $\begin{array}{l}\text { None, except for the } \\
\text { requirement of a Service } \\
\text { Provider Visa (SPV), and } \\
\text { the conditions attached to } \\
\text { entry and temporary stay } \\
\text { under such a visa, as } \\
\text { specified in Annex } 1 .\end{array}$ & $\begin{array}{l}\text { X undertakes the obligations } \\
\text { specified in Annex } 2 .\end{array}$ \\
\hline
\end{tabular}

The preliminary schedule envisages horizontal commitments on mode 4, applying to all sectors with a common skill threshold for purposes of convenience. However, if certain Members are willing to make deeper commitments in specific sectors (e.g. more liberal market access or entry for lower level of skills), then this model can easily be adapted to allow for both horizontal and sectoral commitments 


\section{Annex 1: Conditions and Qualifications}

1. A special permit, entitled a "Service Provider Visa (SPV)", can be obtained by nationals of other WTO Members from X, when the applicant falls under the categories listed under Categories 1, 2 and 3 specified in the market access column above.

a) For natural persons falling under Categories 1,2 and 3 above, the SPV will be extended strictly to personnel with requisite qualifications to fill positions responsible either for management of operations, or provision of services at a level of complexity and specialty that require, at a minimum, a diploma or a university degree, or demonstrated experience.

b) Applicants seeking a SPV under all categories must fulfill certain specific requirements regarding information necessary to support the application, proof of employment with current employer for categories 1 and 2, specific service contract(s) and/or invitation and declaration of intention not to stay for a period of more than twelve months.

c) The SPV fees should reflect actual administrative costs.

d) For persons falling under Categories 1, 2, and 3 the SPV will be authorized for a period of 3 years, allowing for multiple entry, with no single stay exceeding one year.

e) For Categories 1,2 and 3, the provisions for renewal of the permit shall be based on the permit holder's continued status, as defined in 2 (a) above, as an employee of the same company or partnership for Categories 1 and 2, and the absence of abuse of any of the conditions governing the use of the permit. SPV holders must seek renewal no later than one month from the date of expiration of the permit.

f) Wage parity will not be a condition for the issuance, or apply to holders, of Categories 1,2 or 3SPVs.

g) Category 2 and 3 permits are subject to the following conditions and are subject to renewal every 3 years:

i. all applications must be accompanied either by a copy of a contract(s)made between the employer and a client(s) in X, demonstrating terms and conditions of the contract, as well as its monetary value, or an invitation to the service provider from a potential client/industry association/professional body.

ii) The SPV holder is permitted to stay in X for the duration of the contract(s), or 365 days, whichever is less. Remuneration provided under the contract(s) must specify payment to the employer alone for Category 2 and service provider alone for Category 3 as a condition for issuing the SPV.

h) Applicants under Categories 1, 2 and 3 must submit information pertaining to level of education, qualifications (including professional accreditation when required in the home country), and proof of citizenship.

i) Holders of SPVs are not authorized to change their status to another non-immigrant visa category while using the SPV. 
j) Penalties. For Category 1 and 2 SPV holders, abuse of the programme will result in a one year programme prohibition.

k) Special Safeguards. Where it can be established that a pattern of practice among a number of companies of another Member has led to fraudulent use or misrepresentation of the SPV, the programme may be suspended for a temporary period of time with respect to that Member, not to exceed one year.

1) The SPV for both Category 1 and Category 2 persons will be issued without unreasonable delay and in any event no later than three weeks following the satisfactory presentation of documentation required by $\mathrm{X}$.

m) Where the SPV is denied, the applicant will have an opportunity to appeal the decision and obtain a determination within one month from the time the appeal is lodged. SPV renewal procedures will follow the same conditions and maximum time frame for issuance or denial.

\section{Annex 2: Additional Commitments}

Transparency

Authorities in X will:

1. Make available, in a consolidated text, all measures, in particular administrative measures, and any descriptive material accompanying such measures that pertain to the temporary admission of natural persons covered by this commitment (defined as entry, stay, and work authorization). Where possible, $\mathrm{X}$ will provide this information electronically, on web-sites or otherwise.

2. As part of the consolidated text, provide information on the materials or evidence required of an applicant seeking temporary admission into $\mathrm{X}$, as well as a description of the complete process for its submission, consideration, and approval. Information provided will include:

- Categories of permit and their requirements;

- Documentation required;

- Method of lodgement;

- Processing time and application fees (if any);

- Length and validity of stay;

- Possibility and conditions for extensions (including availability of multiple entry visas);

- Rules regarding accompanying dependants;

- Review and/or appeal procedures (if any);

- Details of relevant contact points for further information (e.g. links to relevant government web-sites which provide more detailed information on embassies, Consulates and other issuing bodies).

- Any relevant immigration laws of general application should also be referenced (not necessarily included in full, but details of where information can be found on them).

3. Grant approval of applications for temporary admission within a defined period of time, and provide notice when any such deadlines cannot be achieved. 
4. As part of the consolidated text, provide a full description of the manner in which any limitations to market access and national treatment for the temporary entry of natural persons are administered by their authorities.

\section{[Prior Comment][Prompt Notification]}

[1. For new measures or alterations to existing measures that are being proposed by $\mathrm{X}$, interested parties will be given a reasonable period of time to comment on any such proposed measures that would govern the temporary entry and stay of natural persons. Procedures will be followed that provide for public notice, on a timely basis, to any interested party who wishes to make comments, with a reasonable period of time allowed for the submission of views. Measures that would be subject to prior comment would include visa conditions and procedures to obtain them; changes or additions to worker categories covered by visa procedures; work permit conditions and economic needs tests; and any other proposed measure directly affecting the temporary entry and stay of natural persons covered by this commitment. Provided that the prior comment procedure can be waived when a measure is needed to address urgent problems of safety, health, environmental protection, and national security.]

OR

[1. Any new measures or modifications of existing measures by X will be notified to the WTO within one month of their publication by $\mathrm{X}$, and the information will also be made available electronically through the relevant websites.]

2. Except for the urgent circumstances in (1) above, $X$ will allow a reasonable interval between the publication of the measure in proposed form domestically and its notification to the WTO, and its subsequent entry into force, in order to allow time for affected parties to become acquainted with it.

\section{Domestic Regulation}

1. (a) Any qualification requirements and procedures, technical standards and licensing requirements applied to foreign natural persons under categories 1,2 and 3 shall not be more stringent than international standards and requirements, except when such international standards and requirements are ineffective or inappropriate means for the fulfillment of legitimate objectives.

(b) When such international standards do not exist or when it is necessary to depart from international standards, a foreign professional's competence to provide a service shall be verified by administering a test of professional competence and/or educational attainment.

(c) Where necessary, a foreign professional may be required to make up objectively verifiable deficiencies in education, training and experience.

2. In concluding Mutual Recognition Agreements (MRAs), X will follow the principles stated in the Multilateral Guidelines for MRAs developed for the Accountancy sector. 


\section{Contact Point}

$\mathrm{X}$ will establish a contact point at authorized departments for both trade and immigration, allowing business persons to report on examples where they have encountered special difficulties in the process of seeking temporary entry and stay in another country. 


\section{References}

Chanda, Rupa. 2002. "Movement of Natural Persons and the GATS Major Trade Policy Impediments." In Bernard Hoekman, Aaditya Mattoo and Philip English eds., Development, Trade and the WTO. Washington, DC: World Bank.

Desai, Mihir A., Davesh Kapur and John McHale. 2001. "Sharing the Spoils :Taxing International Human Flows." Weatherhead Center for International Affairs Working Paper 02-06. Harvard University, Cambridge, Mass.

Hatcher, Mark (2003). "Draft Model Schedule for Mode 4: A Proposal." in Mattoo and Carzaniga.

Henry, Paul (2003). "Mode 4: Through a Canadian Immigration Policy Lens." in Mattoo and Carzaniga.

Hira, Ron (2003). "Utilizing Immigration Regulations as a Competitive Advantage: An Additional Explanation for India's Success in Exporting Information Technology Services." CSPO Working Paper, Columbia University.

Lowell, Lindsay B. (2000). "H-1B Temporary Workers: Estimating the Population." Working Paper No. 12, Center for Comparative Immigration Studies, University of California, San Diego.

Mattoo, Aaditya and Antonia Carzaniga (2003). "Moving People to Deliver Services." Oxford University Press and World Bank, Washington, D.C. (forthcoming).

Nielson, Julia (2003). "Labour Mobility in Regional Trade Agreements.” in Mattoo and Carzaniga.

Nielson, Julia and Oliver Cattaneo (2003). "Current Regimes for the Temporary Movement of Service Providers: Case Studies of Australia and the United States." in Mattoo and Carzaniga.

OECD (2000). "Service Providers on the Move: A Closer Look at Labor Mobility and the GATS." Working Party of the Trade Committee, TD/TC/WP(2001)26/FINAL, OECD, Paris.

Page, Pierre E. (2003). "The Temporary Inflow of Natural Persons for the Swiss IT Market." in Mattoo and Carzaniga.

Parikh, Vaibhav V. (2003). "Mode 4 and the Software Services Sector: An Indian View." in Mattoo and Carzaniga.

Self, Richard B. and B.K. Zutshi (2003). "Mode 4: Negotiating Challenges and Opportunities." in Mattoo and Carzaniga.

Waghorne, Mike (2003). "Mode 4 and Trade Union Concerns." in Mattoo and Carzaniga.

Wibulpolparsert, Suwit (2003). "International Trade and the Migration of Healthcare Workers: Thailand's Experience." in Mattoo and Carzaniga.

Winters, L. Alan, Terrie L. Walmsley, Zhen Kun Wang and Roman Grynberg. 2002. "Negotiating the Liberalisation of the Temporary Movement of Natural Persons." Economics Discussion Paper 87. University of Sussex, Brighton.

Winters, Alan (2003). "The Economic Implications of Liberalising Mode 4 Trade." in Mattoo and Carzaniga. 